\title{
INSTRUÇÕES AOS COLABORADORES RBEP
}

\section{APRESENTAÇÃO}

Criada em 1944, a Revista Brasileira de Estudos Pedagógicos (RBEP) é um periódico quadrimestral, publicado em formato impresso e eletrônico. A RBEP publica artigos inéditos, resultantes de pesquisas que apresentem consistência, rigor e originalidade na abordagem do tema e contribuam para a construção do conhecimento na área de Educação. A RBEP também publica relatos de experiência e resenhas. A RBEP não aceita textos que tenham sido enviados concomitantemente a outras revistas e que não atendam a princípios éticos de pesquisa. Seu público-leitor é formado por professores, pesquisadores e alunos de graduação e pós-graduação, técnicos e gestores da área educacional.

A RBEP compõe-se das seguintes seções:

- Estudos - artigos resultantes de pesquisas empíricas e teóricas com objetivos claros, fundamentação teórica e adequação metodológica que respaldem a discussão apresentada, considerando que:

- pesquisas empíricas devem explicitar procedimentos de pesquisa, critérios para constituição da amostra ou seleção dos sujeitos, métodos de coleta, construção e análise dos dados.

- pesquisas teóricas devem evidenciar elaboração original sobre o tema ou questão de relevância para a área de Educação. 
- Relatos de Experiência - artigos teoricamente fundamentados, oriundos de projetos de ação pedagógica em contextos de educação que analisem criticamente a experiência vivida.

- Resenhas - análise crítica de livros ou filmes lançados nos últimos três anos relacionados à educação. As resenhas devem apresentar título, referência da obra, dados dos autores/diretores da obra resenhada, resumo e posicionamento analítico do resenhista sobre as contribuições da obra para a área.

\section{NORMAS EDITORIAIS}

Os artigos deverão ter entre 28.000 a 50.000 caracteres (com espaços) e poderão ser redigidos em português, espanhol ou inglês e ser encaminhados em qualquer época.

Os artigos são avaliados por consultores ad hoc de reconhecida competência nos temas abordados, diversificados regional e institucionalmente, com parecer final da Editoria Científica. Os artigos são encaminhados sem identificação de autoria, para garantir a imparcialidade na avaliação.

Os aspectos considerados na avaliação dos artigos são os seguintes:

- Questões referentes à forma: aspectos gramaticais e estilísticos.

- Questões referentes ao conteúdo: a importância do tema abordado, a definição da questão principal, a estrutura, o desenvolvimento e a conclusão do trabalho.

Os pareceres envolvem três tipos de julgamento:

- Aprovado - o artigo é programado para publicação.

- Aprovado com modificações - são solicitados ao autor ajustes ou reformulações no artigo, com o envio de nova versão para avaliação final.

- Não aprovado - o artigo é recusado.

A aprovação final dos artigos é de responsabilidade da Editoria Científica da RBEP.

O atendimento das condições especificadas nas "Normas gerais para apresentação de originais" é imprescindível para a publicação do artigo.

A aceitação do artigo implica automaticamente a cessão dos direitos autorais relativos ao trabalho ao Instituto Nacional de Estudos e Pesquisas Educacionais Anísio Teixeira (Inep). 


\section{NORMAS GERAIS PARA A APRESENTAÇÃO DE ORIGINAIS}

A fim de facilitar o tratamento e a disseminação dos trabalhos enviados para publicação nos periódicos do Inep, apresentamos algumas normas técnicas para o estabelecimento de padrões de estilo e de apresentação dos textos.

\section{Diretrizes para Autores}

\section{1 - Submissão}

Os artigos e resenhas deverão ser encaminhados exclusivamente por meio do Sistema de Editoração Eletrônica de Revistas (Seer), cujas instruções se encontram disponíveis no site: htpp://www.rbep.inep.gov.br

\section{2 - Normas para submissão de artigos}

2.1 Idiomas: os artigos poderão ser redigidos em português, espanhol ou inglês.

\subsection{Autoria:}

2.2.1 O número de autores por artigo não poderá exceder o total de quatro pessoas. Caso mais pessoas tenham participado da construção do artigo, recomenda-se mencionar em nota de rodapé o grau de colaboração de cada participante da pesquisa, caracterizando-as como estagiários, auxiliares de pesquisa, bolsistas etc.

2.2.2 A identificação de autoria do artigo deve ser removida, assim como devem ser retirados do texto todos os nomes de autores, grupos de pesquisa e de instituições. E preciso também remover a autoria do arquivo e da opção Propriedades no Word, garantindo desta forma o critério de sigilo da revista, caso submetido para avaliação por pares, conforme instruções disponíveis em: www.rbep. inep.gov.br.

2.3 Mídia: os originais deverão ser encaminhados em arquivo formato Word, digitados em espaço 1,5, com extensão de 28.000 a 50.000 caracteres, incluindo os espaços. A extensão do artigo inclui título, resumo e as palavras-chave, nos dois idiomas. Os arquivos não devem exceder o tamanho de 2MB. 
2.3.1 O nome dos arquivos enviados não pode ultrapassar a extensão de 85 caracteres.

2.4 Fonte: a fonte utilizada deverá ser a Times New Roman, em corpo 12 para o texto, corpo 10 para as citações destacadas e corpo 8 para as notas de rodapé.

2.5 Ilustrações: a revista é impressa em preto e branco e as ilustrações deverão possuir resolução a partir de 300 dpi, acompanhadas das fontes e de título que permitam compreender o significado dos dados reunidos. Os quadros, tabelas e gráficos (de preferência em Excel) deverão obedecer às normas de apresentação tabular do Instituto Brasileiro de Geografia e Estatística (IBGE).

2.6 Título: o título do artigo deve ser breve (máximo de 200 caracteres com espaço), específico e descritivo, contendo palavras representativas do seu conteúdo, e vir, também, traduzido para o inglês.

2.7 Resumos: os artigos deverão ter, obrigatoriamente, resumos informativos em português (ou espanhol) e inglês, com até 1.500 caracteres com espaço.

2.7.1 Os resumos devem conter informações qualitativas e quantitativas e dados essenciais, tais como:

a) Descrição - indica o tipo de artigo a ser analisado (artigo original, de revisão, estudo de caso);

b) Objetivo - descreve as razões pelas quais o trabalho foi realizado, o que se buscou demonstrar e a natureza do problema tratado;

c) Metodologia - descreve a abordagem teórica e/ ou metodológica empregada, as principais técnicas utilizadas, indica as fontes dos dados e o modo como estes foram utilizados, quais os conceitos desenvolvidos e como foram analisadas as variáveis; e

d) Resultados - descreve sucintamente as descobertas significativas e importantes da pesquisa.

2.8 Palavras-chave: os artigos devem apresentar palavras-chave referentes ao seu conteúdo, escolhidas em vocabulário controlado: Thesaurus Brasileiro de Educação, disponível em www.inep.gov.br/pesquisa/thesaurus e devem vir traduzidas para o inglês. 
2.9 Citações: as citações devem seguir as normas da Associação Brasileira de Normas Técnicas (ABNT):

2.9.1 As citações com até três linhas devem vir entre aspas, dentro do parágrafo, acompanhadas por uma chamada entre parênteses para o autor, o ano e o número da página da publicação.

2.9.2 As citações com mais de três linhas devem ser destacadas com recuo, sem aspas, em corpo 10, redondo.

2.9.3 A referência bibliográfica completa da citação virá em lista única ao final do artigo.

2.9.4 A exatidão e a adequação das citações e de referências a trabalhos consultados e mencionados no texto são de responsabilidade do autor do artigo submetido.

2.10 Notas: as notas de rodapé devem ser evitadas. Se necessárias, devem ter a finalidade de oferecer observações complementares; realizar remissões internas e externas; introduzir uma citação de reforço ou fornecer a tradução de um texto. As indicações das fontes bibliográficas deverão ser feitas no texto.

2.11 Referências bibliográficas: as referências bibliográficas devem constituir uma lista única no final do artigo, em ordem alfabética por sobrenome de autor; devem ser completas e elaboradas de acordo com as normas da ABNT - NBR 6.023.

2.11.1 Quando se tratar de obra consultada online, faz-se necessário indicar o endereço eletrônico e a data em que foi acessada; se a obra estiver em suporte eletrônico (DVD, CD-ROM), essa informação também deve constar após a sua identificação.

2.11.2 Todos os endereços de páginas na Internet (URLs), incluídos no texto (ex.: http://www.ibict.br) devem estar ativos e prontos para clicar.

2.12 Siglas: as siglas devem vir acompanhadas do nome por extenso.

2.13 Destaques: o uso de negrito deve ficar restrito aos títulos e intertítulos; o de itálico, apenas para destacar conceitos ou grifar palavras em língua estrangeira. 


\section{3 - Normas para submissão de resenhas:}

3.1 - Em relação aos aspectos formais, as resenhas deverão seguir as mesmas normas indicadas para artigos, observando-se as seguintes especificidades:

a) devem apresentar título em português e inglês;

b) devem possuir extensão máxima de 10.000 caracteres, considerando os espaços;

c) devem apresentar no máximo dois autores.

\section{4 - Importante}

4.1 - A exatidão das informações e os conceitos e opiniões emitidos nos artigos e resenhas são de exclusiva responsabilidade dos autores, não refletindo, necessariamente, a opinião da editoria da revista.

4.2 - O setor de revisão reserva-se o direito de efetuar alterações nos originais, respeitados o estilo e as opiniões dos autores, com vistas a manter a homogeneidade e a qualidade da revista.

4.3 - Os autores receberão três exemplares da revista pelo trabalho publicado. 